\title{
Bet $v 1$ and homologous food allergens are similarly processed by antigen-presenting cells but differ in T cell reactivity
}

\author{
Claudia Kitzmueller ${ }^{1 *}$, Nora Zulehner ${ }^{1}$, Anargyros Roulias ${ }^{2}$, Peter Briza ${ }^{2}$, Fatima Ferreira ${ }^{2}$, Barbara Bohle ${ }^{1}$ \\ From 5th International Symposium on Molecular Allergology (ISMA 2013) \\ Vienna, Austria. 6-7 December 2013
}

\section{Background}

Various plant foods, e.g. apple and celery, express proteins that are homologues of the major birch-pollen allergen Bet v 1, e.g Mal d 1 and Api g 1. The proteins have 63\% and $72 \%$ sequence similarity with Bet $\mathrm{v} 1$ and share with it a common 3-dimensional structure. Despite this great molecular similarity, Bet $\mathrm{v} 1$ is the only one among its homologues with the ability to sensitise atopic individuals. The aim of this study was to assess whether differences in the uptake and processing by antigen-presenting cells and in the presentation to $\mathrm{T}$ cells could be responsible for Bet $v$ 1's ability to sensitise.

\section{Methods}

Uptake of allergens by PBMC, surface binding to and degradation by monocyte-derived dendritic cells (mdDC) were assessed. Peptides derived from digestion of Bet $\mathrm{v} 1$, Mal d 1 and Api g 1 by endo-lysosomal extracts were analysed by mass spectrometry. Epitope-specificity of allergen-specific $\mathrm{T}$ cell lines from birch pollen-allergic individuals with associated food-allergies was mapped using synthetic 12-mer peptides. Binding of allergenderived peptides by HLA class II molecules was analysed in silico.

\section{Results}

Significant differences were found neither in surface binding, in the kinetics of uptake by PBMC, the intracellular degradation by $\mathrm{mdDC}$ nor in the degradation by endo-lysosomal extracts. An immunodominant T cell epitope was found only in Bet $\mathrm{v}$ 1, but could not be referred to preferential binding to the most common HLA class II molecules.

${ }^{1}$ Medical University Vienna, Pathophysiology and Allergy Research, Vienna, Austria

Full list of author information is available at the end of the article

\section{Conclusion}

The ability of Bet $\mathrm{v} 1$ to sensitise is not conferred by differential antigen-processing but might stem from differences in $\mathrm{T}$ cell reactivity and the diverse routes of uptake of the aeroallergen Bet $\mathrm{v} 1$ and the food allergens.

\section{Authors' details \\ ${ }^{1}$ Medical University Vienna, Pathophysiology and Allergy Research, Vienna, Austria. ${ }^{2}$ University of Salzburg, Molecular Biology, Salzburg, Austria.}

Published: 17 March 2014

doi:10.1186/2045-7022-4-S2-012

Cite this article as: Kitzmueller et al: Bet $v 1$ and homologous food allergens are similarly processed by antigen-presenting cells but differ in T cell reactivity. Clinical and Translational Allergy 2014 4(Suppl 2):O12.

Submit your next manuscript to BioMed Central and take full advantage of:

- Convenient online submission

- Thorough peer review

- No space constraints or color figure charges

- Immediate publication on acceptance

- Inclusion in PubMed, CAS, Scopus and Google Scholar

- Research which is freely available for redistribution

Submit your manuscript at www.biomedcentral.com/submit
() Biomed Central 